\title{
PROBLEMS OF IMPLEMENTING THE SOVEREIGNTY OF SMALL BALKAN COUNTRIES ON THE EXAMPLE OF NORTH MACEDONIA
}

\author{
Zeinab BAHTURIDZE \\ E-Mail: zeinabb1000@list.ru \\ Professor, Higher School of International Relations, \\ Peter the Great St. Petersburg Polytechnic University, Saint-Petersburg
}

\section{Natalia VASILIEVA}

E-Mail: n52basil@gmail.com

Professor, Department of International Relations, Saint-Petersburg State University, Saint Petersburg,

\begin{abstract}
The article deals with issues related to the difficulties in implementing the sovereignty of North Macedonia in the context of the international relations system transformation and the formation of a new world order structure. The processes of disintegration that led to the breakup of Yugoslavia and the emergence of newly independent states on the world map set them a number of tasks that had to be resolved. They had to build their own domestic and foreign policy without any proper experience. For North Macedonia, the process of establishing a working State was extremely difficult. It was accompanied by problems in the economic and socio-political sphere, the fight against separatist tendencies, and the need to find solutions to ethnic conflicts. Under these circumstances, the government had to find a balance in the legal and educational fields, which can be considered a success on the way to forming a multi-ethnic society that can become a stable basis for creating a civil nation. Obviously, the country expected assistance from European structures as it attempted to solve difficulties and problems that it was not possible for a small State to overcome on its own. It showed a willingness to join NATO and the EU, primarily to ensure security, as well as the economic and social well-being of its citizens. Despite the numerous difficulties and obstacles, it is clear that North Macedonia is following the designated course, and
\end{abstract}


some success may indicate the right choice.

Key words: small States, Western Balkans, sovereignty, statehood, Albanians, EU, NATO, Turkey, Greece, Bulgaria, Chinese initiative "Forum 16+1" North Macedonia.

\section{Introduction}

This year the United Nations Organization celebrates its 75th anniversary. The UN had a significant impact on the processes of peoples' selfdetermination, which led to the formation of a large number of States. Today there are 193 member States, compared to the 51 that signed the original UN Charter. Moreover, a large number of these are small State, both in terms of population and territory. The last wave of peoples' self-determination occurred in the 1990s, when the USSR, Yugoslavia and Czechoslovakia disappeared from the political map of the world. The question naturally arises as to the sovereignty of the newly independent States that fall under the concept of small States in their domestic and foreign policy. According to the UN Charter, the organization is based on the principle of equality of all its members, which therefore can participate equally in world policy and economy as sovereign subjects of the international system. According to Georgian researcher Alexander Rondeli: "in our politicized world, where it is still very important to have economic and military power, which primarily determine the 'strength' and role of a state in international relations, small States have a special place and interest in them is rapidly increasing. Of particular interest is the problem of the survivability and 'viability' of small Sates, their role in the international political and economic systems, as well as the processes and features of the young independent state's statehood establishment" (Rondeli). There is no doubt that gaining international recognition is a difficult task. This is especially true for small States that are, for the first time, showing themselves as international relations and world politics actors.

It is important to emphasize that the present stage of statehood development is interesting due to the duality of the processes when, on the one hand, there is a growing desire some to implement the principle of selfdetermination of peoples, enshrined in the UN Charter (e.g., Scotland, Catalonia), and become independent States and on the other hand, does not weaken the trend towards the integration of States to institutionalise the political-economic and strategic stability of development through such organizations as EU, EEU, ASEAN NATO, and CSTO.

\section{North Macedonia: current state and prospects of statehood development}

Under these conditions, it is important to consider the current state and prospects for the development of the statehood of North Macedonia, which makes it possible to understand the problems of the newly independent states 
of the Balkan region that fall under the concept of "small States". While characterizing any state, it is important to consider the demographic, ethnoconfessional, socio-economic and political context of the country. Moreover, it is necessary to take into consideration the geopolitical factors that characterize the State's position in relation to its neighbors, the region and the world political system as a whole.

The latter circumstance is especially important when characterizing the real content of the meaning "sovereignty" in the first half of the 21 st century. Indeed, the international obligations of the States have greatly limited their sovereignty, which of course also affects human rights issues (Aver'yanov, 1993). In addition, economic globalization, through the role of the World Trade organization as the arbiter of numerous integrational processes, has led to a limitation of sovereign rights. This fact is associated with the need to unify standards and tariffs and regulate prices for essential energy resources, among other economic issues. In the field of world politics, there is also a limitation on the absolute sovereignty of States in matters of war and peace, which is enshrined in the UN Charter, according to which the Security Council has the right to regulate supranational conflict relations between States. According to L. E. Grinin, "the internal affairs of the state, in which no one interferes and which are regulated only by national law and customs, are being limited, and international or community law is expanding" (Grinin, 2005, p.18).

Methodology says that issuing a question of the sovereignty principle effectiveness in relation to the small States of the Balkan region can be carried out on the basis of conceptual neo-institutionalism developments, which emphasizes the importance of the State. The State, like other institutions, is a normative and legitimate model of social relations that has the potential to solve social development problems.

According to North's neo-institutional theory classic, the beliefs and institutions that humans have devised only make sense as an ongoing response to the various levels of uncertainty that humans have confronted and continue to confront in the evolving physical and human landscape (North, 2005, pp. 1415). Adherents of neo-institutional theory focus on the role of institutional choice in the development of the political system as a whole. At the same time, a special role is assigned to a set of factors, both internal and external, the ratio of which determines the ability of a particular nation to build its own system of statehood and take a certain place in the system of international relations.

For some time, political science has discussed the idea of the concept of national sovereignty "obsolescence" (Kissinger, 2001, p. 263), the need for "a comprehensive rethinking and re-evaluation of the 'sovereignty' concept both in connection with the world political community emergence, and in connection with the private sovereignties limits clarification, the principles of their combination with each other and the construction of their hierarchy" (Aver'yanov, 1993, p. 368). It is important to mention the position of the British scientist R. Cooper who sees the new characteristics of relationship in the development of the European countries, which are not based on the balance of power but on the on the voluntary limitation of their sovereignty by allowing 
external interference in case of violation of the agreements reached (Cooper, 2003). According to L.G. Grinin many researchers "underestimate the seriousness of changes in sovereignty and the need to revise this very concept" (Grinin, 2005, p. 18). The legal aspect of such a discussion was also quite popular, and it reflected in the works of Stephen D. Krasner и Neil MacCormick (Krasner, 1999; MacCormick, 1999) but in the conditions of the first half of the 21 st century, structural changes in the world system require a corresponding revision of the international law main concepts. In this regard, it is important to mention Rosenau's concept on the turbulence of world politics, where the state of turbulence indicates the collapse of the old world system and the formation of a new one, the contours of which are not yet known. This theoretical position is especially important for understanding the state-forming processes in the Balkans, where the state of turbulence is particularly pronounced.

Regarding to the problem of North Macedonia establishing statehood, it is necessary to understand the principles that might help it to escape the crisis that has shaken the country almost throughout the entire period of its independence. The methodological approach of the Russian researcher, Ponomareva, to the Macedonian statehood analysis based on the conceptual development of A. Leiphart, supplemented by Lembruch, D. Horowitz, B. Reilly, G. Hale et al., is called the consociational model (Ponomareva, 2010). Ponomareva notes that "the implementation of the consociation model in the statehood formation process requires compliance with certain conditions, including: the exercise of power by a large coalition representing all significant segments of society; proportionality in the formation of all branches of government; mutual veto power in making socially important decisions as a guarantee of taking into account the interests of minorities and a high degree of autonomy of segments of society in solving internal issues of each group" (Ponomareva, 2010). If this model is applied to the current situation in North Macedonia, the consensus seems to be optimal if representatives of all ethnic communities are included in the governance process as much as possible.

North Macedonia is located in the central part of the Balkan Peninsula. It borders Albania to the West, Serbia and partially recognized Republic of Kosovo to the North, Bulgaria to the East, and Greece to the South. The Capital Is Skopje. The official languages are Macedonian and Albanian; in areas where members of national minorities live local language is also used. North Macedonia is one of the small States with a population of just over 2 million. Its area is $25,333 \mathrm{~km}^{2}$. Almost half of the population is represented by people from age 25 to 45 , which indicates a great potential of human capital. However, the distribution of the population (57\% urban, $43 \%$ rural) indicates an underdeveloped economy, which, as a result, leads to a low standard of living and a high level of unemployment.

After the collapse of Yugoslavia, the newly independent state faced problems developing statehood and gaining sovereignty, both in building a multi-ethnic community within the country and in relations with neighboring states:

- at the initial stage, there were no armed forces; 
- Greece refused to accept the name of the state as Macedonia;

- Bulgaria denied the existence of a language and, consequently, a nation, since they claim that Macedonian is a dialect of Bulgarian;

- Serbia did not recognize the political borders nor the independent Macedonian Orthodox Church;

- Albania demanded a radical solution to the problems of the Albanian ethnic minority.

Based on all these crisis components, many experts did not see any prospects for a positive development of the situation, and applied the UN term "failed state" Macedonia. However, the State managed to survive.

In September 2021, the Republic of North Macedonia will celebrate the 30th anniversary of its Declaration of Independence which was made possible thanks to the bloodless secession from the multinational Federation of the Balkan peoples, Socialist Federal Republic of Yugoslavia. We shall agree with the Russian researchers claim that "despite the bloodless nature of the separation from Yugoslavia, the Republic of North Macedonia faced the same difficulties as its neighbors, namely, the unmanageable process of 'Balkanization', which consists in the continuous fragmentation of states on the basis of ethnic and religious contradictions." (Baranov, Smirnov, 2020, p. 240).

The state was recognized by the international society and joined the UN initially under the name of the Former Yugoslav Republic of Macedonia (FYROM). During almost all the years of its independent existence, Macedonia has been looking for a solution of the conflict with Greece over the name of the country. The authorities of Greece consider the historical Macedonia to be one of the Greek's regions, so the new Balkan state should change its name.

According to the authors of the article "Macedonian Question Reframed: Politics, Identity and Culture in Republic of Macedonia", Greece used an embargo in February 1994 as an economic pressure on Macedonia. "[T]his decision of the Greek government had a terrible impact on the economy of Macedonia, which was already somewhat unstable during the transition period", and "the bad economic situation contributed to inter-ethnic tensions and the growth of nationalism in Macedonia" (Stojanovski, Marolov, Ananiev, 2014, p. 308).

In 2008, Greece blocked Macedonia's entry into NATO. During almost the entire 30 years of Macedonia's existence, consultations were held with Greece, resulting, in June 2018, in the Prespa Treaty, changing the name of Former Yugoslav Republic of Macedonia to the Republic of North Macedonia. However, this issue, which was put to a referendum and caused great political controversy in Macedonian society. Only 37\% of citizens took part in the vote, although more than $90 \%$ of these voted to change the country's name. The Parliament recognized the results as legitimate and on February 12, 2019, the State officially became known as North Macedonia. The international community has recognized the legitimacy of the renaming. However, according to opinion polls, $62 \%$ of Greeks perceive the signed agreement negatively, which indicates a complex and long process of settling relations between neighbors (Alekseeva). 
Relations with Bulgaria are no less difficult, although Bulgaria was the first country to recognize the new sovereign State. However, in 2012 Bulgaria and Greece presented a united front, thereby denying a date to be determined for the Macedonia's accession to the EU process. As noted by the Russian expert Dunaev, Bulgarians believe that Macedonians are actually Bulgarians who, as a result of the Second Balkan War, won by Bulgaria, and the First World War, lost by Bulgaria, ended up in Yugoslavia, where the idea of Macedonia as an independent nation was forcibly imposed upon the the people living in that region. At this time, a significant number of Serbian words were added to the language to make it less like Bulgarian (Dunaev). However, at present, inter-state relations are improving, which was reflected in the signing of the Treaty of Friendship, Good-neighbourliness and Cooperation in 2017.

The most difficult problem of statehood building in North Macedonia seems to be the Albanian problem. Since its independence there has been a question of the special status of the Albanian minority, which currently makes up about $25 \%$ of the country's population. The Albanians are a dominating ethnic group in the North-West of the country, with about $70-75 \%$ of the Albanians in North Macedonia living in the cities of Tetovo and Gostivar. According to the Constitution of 1991, North Macedonia is a unitary state. In the original version of the country's main law, it was set forth that Macedonia is the "national state of the Macedonian people", but this wording caused strong discontent among the Albanians and led to a serious inter-ethnic conflict.

As a result, Albanians refused to participate in the political life of the country, in particular they "boycotted the independence referendum on September 8, 1991, and on April 3, 1992, at rallies in Struga and Tetovo, the formation of the Autonomous Republic of 'Ilirida' was proclaimed, which included the Western regions of Macedonia with a predominantly Albanian population" (Koloskov, 2016, p.84). In 2001, Macedonia was on the brink of civil and inter-ethnic war when armed clashes broke out between government forces and the Albanian armed opposition, whose representatives declared that they recognized the territorial integrity of Macedonia only in the form of an Albanian-Macedonian Federation, since Albanians, along with Macedonians, are the constitutive people. The interference of the EU and NATO stopped the conflict, brought the conflicting parties to the negotiating table and led to a framework agreement, the Ohrid Framework Agreement of 2001. As the Russian researcher Klimenko notes, "if before the signing of the Ohrid agreement, only 5\% of Macedonian Albanians supported the idea of creating a greater Albania, then a year later - 62\% [did]" (Klimenko, 2015, p. 46). This was largely due to the active propaganda work of the Albanian nationalist forces in Albania itself, seeking to put into practice the idea of pan-albanism, which implied the reunification of all territories where the Albanian ethnic group prevailed over the state-forming one. The major part of the Greater Albania claimed by Albanian nationalists is located within the former Yugoslavia.

The process of establishing the statehood of North Macedonia is also threatened by the activities of organized crime, which uses the country's 
territory to transfer thousands of migrants to Central and Western Europe. As noted by E.A. Koloskov, "there are very serious reasons to believe that the activities of the Albanian mafia have a huge impact on organized crime in the Republic of North Macedonia, and its clashes with law enforcement forces are largely considered by many analysts as inter-ethnic clashes" (Koloskov, 2016, p.86).

The young State, on the one hand, was unable to protect the population from organized crime and ensure the safety of its citizens, and on the other hand, could not defend its national interests in front of its neighbors. In these circumstances, the political elites of Macedonian society found the salvation in the country's political and economic inclusion in the EU and NATO supranational structures. In fact, "since gaining independence in September 1991, Macedonia has sought to consistently implement the idea of integration into the European Union and NATO in its foreign policy" (Baranov, Smirnov, 2020, p. 240). The conclusions made by Rondeli seem to be quite reasonable. $\mathrm{He}$ considers that "the national interests and foreign policy priorities of a small State sometimes go beyond the regional dimension. This is due to the fact that the small States often become the victims of the major Powers' conflicting interests. Political and economic opportunities and actions of small States that are adjacent to major States take on special significance" (Rondeli). In this context, the small States of the Balkan region, in particular, North Macedonia and Albania, proved to be very popular participants of the big geopolitical game of the EU and NATO. At this point we should mention the "Berlin process", which is considered by the expert international community as a tool of the EU's confrontation with Turkey and China over influence in the Western Balkans. The initiative hosts annual EU - Western Balkans summits. In 2017 the initiative Berlin-plus was declared, which aimed at the creation of special funds for the financing of projects in the field of infrastructure, business development and information technologies. At the 2019 summit, it was stated that, despite the need for internal EU reforms, negotiations with new candidates for membership and the Berlin process will continue.

Macedonia has been a candidate for EU membership since 2005. In 2014, President of the European Commission, J. K. Juncker, announced the suspension of the new members accepting process for a period of five years. After this period the "window of opportunity" would be reopened. However, in October 2019, the start of negotiations was blocked by several EU members, including France, Denmark and the Netherlands. France stated that the reforms provided by the North Macedonia and Albania to gain the EU membership are insufficient. Moreover, France called for the fundamental reform of the EU accession process. However, in 2020, a compromise on the negotiations with Albania and North Macedonia was reached.

Then one more serious problem appeared on the way of North Macedonia to the EU: disagreements with Bulgaria regarding the interpretation

\footnotetext{
${ }^{1}$ The sentence was originally written in Russian and the translarion was made by the author
} 
of the results of the Second World War. According to the official Bulgarian historical position, North Macedonia is home to ethnic Bulgarians who were the ideological victims of the Communist regime of Josip Broz Tito, during the existence of Yugoslavia. A new "Macedonian identity and language" was artificially imposed on the Bulgarians living in Macedonia. The role Bulgarians played in a war is also understood in different ways. In Macedonian, history books call the occupation of Bulgarian troops in the territory of southern Yugoslavia "the Bulgarian fascist occupation", and Bulgarian historiography declares the move as the liberation of "our brothers". As noted by Yuranets, the Bulgarian Parliament called on the leadership of North Macedonia not to use the term "fascist occupation" and to remove similar references from the country's monuments. In 2017 the joint historical committee to resolve disputed issues was formed, but the work of the committee was suspended due to the elections in North Macedonia, and then due to the COVID-19 pandemic. As a result, Bulgaria is threatening to block the North Macedonian entry into the European Union (Yuranets).

The sovereignty and national security of North Macedonia largely depend on the foreign policy factor, which is recognized by the majority of the Macedonian establishment. The desire of North Macedonia to join the EU and NATO is explained by the desire of state officials to delegate their sovereign responsibilities for security and economic well-being to these major international organizations, because these functional responsibilities cannot be fulfilled by state bodies on their own, at least not at this stage. The members of the Parliament of North Macedonia voted unanimously for the country's accession to NATO, which happened in 2020. It was the NATO Alliance that actively participated in the settlement of the ethnic conflict in 2001. One positive result of this intervention, along with the future prospect of an existence under the auspices of the EU and NATO, is that it allowed the Macedonian and Albanian populations to reach a political compromise, to the point that in 2019, the Albanian language became the second official language used at all levels.

North Macedonia has long participated in various NATO and US peacekeeping missions in Afghanistan, Iraq, Bosnia and Herzegovina, Lebanon, etc. According to the Russian expert E.A. Koloskov, if "the government can enlist the support of the United States and leading European countries in ensuring security and, first of all, concerning the questions of joining NATO and the EU, it fulfills its duties, if not, than a change of power is likely in the next electoral cycle" (Koloskov, 2016, p. 86).

In a recent survey, the majority of respondents consider the process of globalization to be imposed by powerful countries, with $34,6 \%$ of respondents agreeing that globalization is a process of spreading the power of multinational companies; and is a process of creating a worldwide society. These people "define globalization as the transfer of power from national governments to global institutions" (Drakulovska Cukalevska, I. Dragović, A. Dragović, 2017, p. 108). The authors of the research make an important point that $92 \%$ of respondents believe that "globalization affects the Macedonian context" and 
" $88,2 \%$ of respondents favor the claim that tradition in Macedonian society is gradually being lost", and "half of respondents have agreed that mass consumption and commercialization pose a threat to Macedonian culture." (Drakulovska Cukalevska, I. Dragović, A. Dragović, 2017, p. 108) At the same time the survey results showed that the Macedonian public opinion has an ingrained view of the positive aspects of globalization, such as a sense of security, a higher standard of living, respect for human rights, and a strong economy, all the elements that are inherent in developed countries.

As already noted, the small States are an important part of the world politics as they serve as necessary material for geopolitical planning and the construction of the new world order by major powers. Turkey, Russia, and China (PRC), have payed considerable attention to the Balkan region. The "forum 16+1" of 2012 was formed on the initiative of the Chinese with the selection of participants being determined by the Chinese. The fact that Albania, Bosnia and Herzegovina, Bulgaria, Croatia, the Czech Republic, Estonia, Hungary, Latvia, Lithuania, Macedonia, Montenegro, Poland, Romania, Serbia, Slovakia, and Slovenia became participants in the process of economic and cultural rapprochement with the PRC contributed to their own rapprochement, as they found common ground in infrastructure projects under the Chinese "One Belt and One Road" strategy. The Russian experts think that the main goal of the platform "16+1" is to strengthen relations between the EU members and five Balkan states of Bosnia and Herzegovina, Serbia, Albania, North Macedonia and Montenegro. The platform " $16+1$ " was institutionalized by creating a Secretariat based in the Chinese Ministry of Foreign Affairs. There seems to be a distinct connection between the "One Belt and One Road" initiative and the "16+1" format, where the $\mathrm{CEE}^{2}$ and Balkan regions are strategic for China in building a large-scale infrastructure project (see: Mikheeva, Shvydko, 2016).

Although China is a strategic partner of Russia, they are on competing sides in the Balkan region. After a period of a diplomatic impotence in the 1990s, Russia has, in recent years, sought to restore traditional historical ties with the peoples of the Balkans. Undoubtedly, Russia has closer ties with Serbia, but the ethnically slavic North Macedonia is also very important for Russian foreign policy and economic interests. Despite the orientation of the North Macedonian leadership in the person of Zoran Zaev on the partnership with Europe and the USA (a strategic partnership agreement was signed with the United States in 2008) and its negative rhetoric against the Russian Federation, a Macedonian-Russian business forum was held in Skopje in November 2019. In his speech, Russian Ambassador Sergey Bazdnikin noted the importance of enhancing interaction between businessmen of the two countries to strengthen trade and economic ties: "in North Macedonia, we see an interesting and promising partner that has great opportunities for mutual cooperation, and its potential is far from exhausted" (Todorovsky). The total volume of trade between Russia and Macedonia in 2019 reached USD 194.5

${ }^{2} \mathrm{CEE}-$ Central and Eastern Europe Region 
million. Macedonian companies delivered goods to Russia totaling USD 52.1 million, and imported almost three times that amount, USD 142.4 million. However, the share of Russian products in North Macedonia's foreign trade is small, only about $1.1 \%$ as of 2019 . Macedonia exports mostly fruits, vegetables and grape wines, tobacco, and raw materials and imports primarily fuel and raw materials. Eighty percent of Macedonian exports go to the EU. The number of Russian tourists in North Macedonia is also small: about $0.6 \%$ of the total number of registered travelers, according to the Macedonian-Russian chamber of Commerce (Todorovsky).

As already noted, the leadership of North Macedonia considers close ties with the EU and NATO to be an external condition for strengthening its sovereignty, but in recent years Turkey's active return to the Balkans has become noticeable, which cannot but affect the formation of Macedonian statehood. During the conquest of the Balkans in the 14th-15th centuries, the Ottoman authorities practiced the migration of the Turk-Muslim population to the Balkans, which significantly influenced the culture and traditions of the peoples of the region. The rise of the Turkish President R. T. Erdogan at the beginning of the $21^{\text {st }}$ century, meant strengthening the Balkan direction of Turkey's foreign policy. So, in May 2018, Erdogan personally spoke at an election rally in Sarajevo, where representatives of the Turkish Diaspora from various Balkan countries gathered. As noted by the Russian expert Svistunova, there was a call for Balkan Turks to preserve their language and religion, raise their children in accordance with national traditions, along with Turkish citizenship, obtain passports of their countries of residence, actively participate in political life in the Balkans, and strive to occupy parliamentary seats in order to pursue a policy friendly to Ankara (Svistunova, 2020, p.66). According to a well-known Turkish politician, Professor A. Davutoglu, the Muslim communities in the Balkans, with their Ottoman heritage, represent the basis of Turkish political influence in the region. Balkan authors of Turkish origin believe that "Turkey, as the heiress of the Ottoman Empire, bears a moral responsibility for providing assistance to the Balkan countries" (Svistunova, 2020, p. 63).

It is important to note that the Turkish leadership actively uses the tools of "soft power", which is reflected in the creation of Turkish universities, schools, and network of cultural centers. Thanks to cultural expansion in the Western Balkans, Turkey can exert pressure on the region, turning this geopolitical space into a zone of its direct influence. As an example, the Russian researcher A.V. Glazova cites a campaign, conducted by the Turks in North Macedonia and other Western Balkan countries, to revise history textbooks in order to remove anti-Turkish and anti-Ottoman formulations. We must admit that the Slavic population of North Macedonia perceives this negatively, considering it an example of the "neo-Ottoman" return of Turkey. The words of Professor A. Davutoglu can serve as the leitmotif of Turkish policy in the Balkans: "the Ottoman era in the Balkans was an era of prosperity, and this time must be returned" (Glazova, 2013, p. 31). 


\section{Conclusions}

The formation of Macedonian statehood involves a complex and often contradictory relationship between internal and external factors. Internal conditions are largely determined by the country's convenient geopolitical location, which, on the one hand, allows it to be a trade and economic hub connecting the Balkan countries and providing opportunities for integration cooperation in the future. On the other hand, the peaceful transition of the Macedonian people to independence testifies to the peaceful nature of the state, which removes the problems of border conflicts. Promising directions for statebuilding include the ability of the Macedonian people to gradually form a multiethnic society, which creates prerequisites for the formation of a civic nation, in particular the solution of problems in education such as learning languages of ethnic minorities, the quotas for admission to higher education, and the question of the participation of ethnic minorities in the power structures.

Regarding external factors, it is worth noting the prevailing significance at the present time. The economic weakness is largely due to the lack of modern production facilities, which leads to high external financial debt. Therefore, the most important structural component of statehood, ensuring the economic and social well-being of its citizens, is formed through international assistance and EU membership. The same problem applies to national security, which depends entirely on North Macedonia's membership in NATO (2020).

Thus, despite numerous problems, over the past almost 30 years of independence of the Macedonian authorities, Macedonian society has made a significant step forward in the construction of its state. 


\section{References}

Alekseeva, N. "Key area of military presence": how Macedonia's accession to NATO may affect the Balkan region Retrieved from https://russian.rt.com/world/article/599757-makedonia-natoprisoedinenie (accessed 20.10.2020) (in Russian).

Aver'yanov, Y. I. (1993) (compiler). Politologiya. Enciklopedicheskij slovar' Moscow. Moscow Commercial University publ., 431 p. (in Russian).

Baranov, N., Smirnov P. (2020) The republic of North Macedonian foreign policy in the context of regional security policy in the Balkans. Balkan Social Science Review. V 15. N 15. Pp. 237-251.

Cooper, R. (2003). The Breaking of Nations: Order and Chaos in the Twentyfirst Century. Atlantic Books, $156 \mathrm{p}$.

Drakulovska Cukalevska, M., Dragović I., Dragović A. (2017). Public opinion toward globalization: the Macedonian experience. Balkan Social Science Review. 2017. Vol. 10. P. 91-113.

Dunayev, A. Through Hardships to the EU and NATO? Retrieved from http://mirperemen.net/2017/09/cherez-ternii-k-es-i-nato (accessed 21.10.2020) (in Russian).

Glazova, A.V. (2013). Turkish policy in the Western Balkans. Problemy nacional'noj strategii [Problems of the national strategy]. No. 2 (17). Pp. 22-34. (in Russian).

Grinin, L. G. (2005). Globalization and national sovereignty. Istoriya i sovremennost' [History and modernity]. No 1. Pp. 6-31. (in Russian).

Kissinger, G. (2001). Does America Need a Foreign Policy?: Toward a New Diplomacy for the 21st Century. Simon \& Schuster Publ., 320 p.

Klimenko, Z. V. (2015) The Albanian question in Macedonia. Vestnik Nizhegorodskogo universiteta im. N.I. Lobachevskogo [Vestnik of Lobachevsky University of Nizhni Novgorod]. No 14. Pp. 38-47. (in Russian).

Koloskov, E.A. (2016). Macedonian National security. Vestnik SPbGU [Vestnik of St. Petersburg State University]. Series 6. Issue 3. Pp. 8292. DOI: 10.21638/11701/spbu06.2016.307 (in Russian).

Krasner, S. D. (1999). Sovereignty: Organized Hypocrisy, Princeton: Princeton University Press, 280 p.

MacCormick, N. (1999). Questioning Sovereignty: Law, State, and Nation in the European Commonwealth. Oxford University Press, 210 p.

Mikheev, V. V., Shvydko, V. G. (2016). (executive editors) China and Eastern Europe: links of the new silk road. Moscow, IMEMO RAS, 70 p. (in Russian).

North, D. (2005). Understanding the Process of Economic Change. Princeton University Press, $187 \mathrm{p}$.

Ponomareva, E. G. (2010). Formirovanie gosudarstvennosti na postyugoslavskom prostranstve: vnutrennie i vneshnie faktory. [Formation of statehood in the post-Yugoslav space: internal and 
external factors]. Extended abstract of Candidate's dissertation in Politics, Moscow.

Rondeli, A. Georgia in the post-Soviet space. Retrieved from http://poli.vub.ac.be/publi/crs/caucasus/rondeli.htm ） (accessed 21.10.2020).

Rosenau, J.N. (1990). Turbulence in World Politics: A Theory of Change and Continuity. Princeton, NJ, Princeton University Press, p. 480.

Stojanovski Strashko, Marolov Dejan, Ananiev Jovan. (2014). Macedonian Question Reframed: Politics, Identity and Culture in Republic of Macedonia // Balkan Social Science Review. Vol. 4. Pp. 295-323.

Svistunova, I. (2020) Turkish Balkan policy: the role of ethnic and religious minorities. Sovremennaya Evropa [Modern Europe], No. 4. Pp. 61-71.

The Berlin process in in relation to the Western Balkans summit in Poznan. Retrieved from http://archiwum.radiopolsha.pl/6/248/Artykul/428607 (accessed 20.10.2020). (in Russian).

Todorovsky, D. Will the relations between Moscow and Skopje change after North Macedonia joins NATO? Retrieved from https://balkanist.ru/izmenyatsya-li-otnosheniya-mezhdu-moskvoj-iskope-posle-vstupleniya-severnoj-makedonii-v-nato/ (accessed: 21.10.2020) (in Russian).

Yuranets, A. The fascist past brought up: Bulgaria does not let North Macedonia into the EU. Retrieved from https://www.gazeta.ru/politics/2020/09/28_a_13271587.shtml (accessed 21.10.2020) (in Russian). 
